\title{
Economic Outcomes of Working-Age People with Disabilities over the Business Cycle: An Examination of the 1980s and 1990s
}

\author{
Richard V. Burkhauser \\ Department of Policy Analysis and Management \\ Cornell University \\ Mary C. Daly* \\ Federal Reserve Bank of San Francisco \\ Andrew J. Houtenville \\ School of Industrial and Labor Relations \\ Cornell University \\ Nigar Nargis \\ Department of Economics \\ Cornell University
}

March 2001

JEL Classifications: J15, J18, J21

We thank J.S. Butler, Tom Hale, Mitch LaPlante, Dave Stapleton, Dave Wittenburg, and participants at the Cornell Employment and Disability Policy Summer Institute and the $7^{\text {th }}$ National Disability Statistics and Policy Forum: Disability and Participation hosted by the Disability Statistics Center University of California, San Francisco, for helpful comments. We also thank Carol D'Souza for research support and Martha Bonney for editorial assistance. None of these individuals are responsible for any errors. This research is funded in part by the United States Department of Education, National Institute on Disability and Rehabilitation Research, cooperative agreement No. 13313980038. It does not necessarily reflect the view of the National Institute on Disability and Rehabilitation Research or the Federal Research Bank of San Francisco.

*Corresponding author: Mary C. Daly, Economic Research Department, Federal Reserve Bank of San Francisco, 101 Market Street, Mail Stop 1130, San Francisco, CA 94105.

Ph: (415) 974-3186, Fax: (415) 977-4054, email: mary.daly@sf.frb.org. 


\title{
Economic Outcomes of Working-Age People with Disabilities over the Business Cycle: An Examination of the 1980s and 1990s
}

\author{
Abstract \\ We examine the rate of employment and the household income of the working-age \\ population (aged 25-61) with and without disabilities over the business cycles of the 1980s and \\ 1990s using data from the March Current Population Survey and the National Health Interview \\ Survey. In general, we find that while the employment of working-age men and women with and \\ without disabilities exhibited a procyclical trend during the 1980s business cycle, this was not the \\ case during the 1990s expansion. During the 1990s, the employment of working-age men and \\ women without disabilities continued to be procyclical, but the employment rates of their \\ counterparts with disabilities declined over the entire 1990s business cycle. Although increases in \\ disability transfer income replaced a significant fraction of their lost earnings, the household \\ income of men and women with disabilities fell relative to the rest of the population over the \\ decade.
}




\section{Economic Outcomes of Working-Age People with Disabilities over the Business Cycle: An Examination of the 1980s and 1990s}

\section{Introduction}

In general, the rate of employment and household income of workers fluctuate with the business cycle, rising during expansions and falling during contractions (Blackburn and Bloom 1989; Burkhauser et al. 1999). Although this pattern holds for the average worker, there is considerable variation in business cycle outcomes across workers with different levels of education, job skills, and work experience (Blank and Card 1993; Hoynes 2000). Research also documents substantial variation in outcomes across the distribution of household income, with workers in lower income households being more vulnerable to economic downturns and less responsive to economic upturns than the average worker (Karoly 1993; Karoly and Burtless 1995).

In this paper, we examine the relative outcomes of workers with disabilities across the business cycle. We find that, on average, the employment rate and household income of workingage people with disabilities are more adversely affected during economic downturns than are those of working-age men and women without disabilities. Our findings with respect to economic expansions are less consistent; a different pattern emerges in the 1990s than in the 1980s. Whereas employment and household income of all groups rose during the 1980s expansion, only the outcomes of working-age men and women without disabilities continued to be procyclical in the 1990s. The employment rates of their counterparts with disabilities declined over the entire 1990s business cycle. While increases in disability transfer income replaced a significant fraction 
Business Cycles and People with Disabilities-2

of their lost earnings, the household income of men and women with disabilities also fell relative to the population without disabilities over the decade.

\section{Data and Measurement Issues}

\section{Data}

We compare the employment and economic well-being of people with and without disabilities over the 20-year period from 1980 through 1999 using data from the March Current Population Survey (CPS). The CPS is a monthly survey of a nationally representative sample of the civilian non-institutionalized United States population, conducted by the Bureau of Labor Statistics. The annual March Demographic Supplement contains detailed questions about household composition, employment, and sources of income, making it a valuable source of timeseries data on changes in economic outcomes over the business cycle. The sample size in each year of the March CPS is in excess of 55,000 households and 150,000 individuals.

We test the robustness of our results using data from the National Health Interview Survey (NHIS) from 1983 to1996. ${ }^{1}$ The NHIS is an annual survey of a nationally representative sample of civilian non-institutionalized United States households. It is conducted by the National Center for Health Statistics and used to monitor trends in illness and disability in the United States population. Each year the NHIS surveys approximately 40,000 households and 100,000 individuals. Because of its focus on health, the NHIS has far more information on illness and disability than the CPS and less information on employment and household income. We use data

\footnotetext{
${ }^{1}$ Although the NHIS survey covers a larger number of years, 1957 through 2000, we restrict our analysis to the subset of surveys with consistently asked questions on work limitations.
} 
from the NHIS to validate the trends in disability prevalence observed in the CPS data and to check the robustness of our CPS-based business cycle results with an alternative data source. Defining the Population with Disabilities

Evaluation of the working-age population with disabilities must start with a definition of that population. Disability is a more complex concept to define or measure than age, race, or gender, and definitions of the population frequently vary by research discipline and policy purpose. $^{2}$ For example, the Americans with Disabilities Act of 1990 (ADA), with the goal of establishing broad civil rights, defines disability as a physical or mental impairment that substantially limits one or more major life activity, a record of such an impairment, or being regarded as having such an impairment. In contrast, the Social Security Administration, with the goal of awarding disability benefits, defines disability as the inability to engage in substantial gainful activity by reason of a medically determinable physical impairment expected to result in death or last at least 12 months.

In the economics literature, researchers' definitions of disability frequently are functions of the available data. In most surveys of employment and household income, the data available on health come from a small set of questions that ask respondents to assess whether their health limits the kind of amount of work they can perform. ${ }^{3}$ The use of self-reported work disability is

\footnotetext{
${ }^{2}$ Mashaw and Reno (1996) argue that the appropriateness of any definition of disability depends on the purpose for which it is used. They document over 20 definitions of disability used for purposes of entitlement to public or private income transfers, government services, or statistical analysis.

${ }^{3}$ Researchers have been cautious in using such global self-reported health measures because they are subjective and can vary from individual to individual. More importantly, health responses may not be independent of the economic variables being examined. For a review of these issues see Bound and Burkhauser (1999).
} 
Business Cycles and People with Disabilities-4

controversial. Self-perception of disability as captured by this measure can be influenced by social context, such as the presence of benefit programs targeted on those with disabilities and workplace barriers or accommodations. Thus, reports of a work disability may change over time, even holding underlying health constant (Kirchner 1996). ${ }^{4}$ While the problems inherent in these measures have led some researchers (Myers 1982, 1983) to conclude that no useful information can be gained from such data, numerous researchers have shown that self-reported measures of work limitations are highly correlated with other more objective assessments of health and with clinical measures of disability (see Bound and Burkhauser 1999 for a review of this literature.) Moreover, as discussed elsewhere (Burkhauser and Daly 1996), we believe such data are capable of identifying people with serious functional limitations.

In the CPS, the population with disabilities is defined by a work-limitations question that asks, "Does anyone in this household have a health problem or disability which prevents them from working or which limits the kind or amount of work they can do? If yes, Who is that? (Anyone else?)" While this single-question measure of work-limitations is coarser than a measure of disability based on a more detailed set of self-reported questions like those in the NHIS or on an actual medical examination, it is a reasonable first approximation of the population

${ }^{4}$ Kirchner argues that self-perception within the population with disabilities changed with the passage of the Americans with Disabilities Act, making people with disabilities less likely to describe themselves as having a work-limiting condition. Below, we test whether such changes in reporting behavior are reflected in changes in the composition of the population with disabilities over time. We also examine whether changes in reporting behavior of the type described by Kirchner are consistent with the outcomes observed in the CPS data.

${ }^{5}$ Small changes were made to the CPS question on disability in 1994. However, in other work we argue that they do not materially affect our results. See Burkhauser, Daly, and Houtenville (2001, the Appendix) for a description of the changes and a discussion of there effects on disability prevalence. 
Business Cycles and People with Disabilities-5

with disabilities. More importantly, we argue below that it allows for consistent measurement of that population over the period of our analysis.

Based on this question in the CPS, we find that, on average, between 1980 and 1999 about 8 percent of the working-age population reported a work-limiting disability in any given year. Men were slightly more likely to report a disability than were women. During the 20-year period, an average of 8.1 percent of men reported having a disability compared to 7.5 percent of women. The complete set of values underlying these averages are listed in Appendix Table 1. Looking beyond the average rate of disability in the population, Figure 1 shows the prevalence of disability by household size-adjusted income decile for three years in the data-1981,1990, and $2000 .^{6}$ In each of these years, the prevalence of disability falls with higher values of household income. This relationship is consistent with the health-income gradient documented in other data sources (Daly et al. 1999; Robert and House 1996; Smith and Kington 1996).

What is more important for our analysis is the fact that there is little difference in the prevalence of disability by income decile over time. This consistency implies that, measured by household size-adjusted income, the composition of the population of those with disabilities has remained relatively constant over the 20 years of our study. Moreover, it suggests that there have not been systematic changes in the way that working-age people with disabilities respond to the CPS work-limitation question and that this question can be used to monitor trends in the employment and household income among the working-age population with disabilities over time.

${ }^{6}$ The measure of household size-adjusted income used in Figure 1 is described in detail in the variable definition section. 
To verify that the patterns we observe in the CPS data are not particular to that survey, we compare CPS prevalence statistics to those obtained from the NHIS. The sample period in our study excludes years before 1983 and after 1996 due to major revisions in the NHIS survey instrument in 1983 and 1997. The work limitation question in the NHIS is: "Does any impairment or health problem NOW keep [person] from working at a job or business? Is [person] limited in the kind OR amount of work [person] can do because of any impairment?" A person with an affirmative response to either question is considered to have a work limitation.

Figure 2 compares the prevalence of disability based on global work-limitations questions in the CPS and the NHIS over our sample period for working-age men and women. The average annual prevalence of disability among men over the period from 1983 through 1996 is 8.1 percent using the CPS-based estimates, and 10.3 percent using the NHIS-based estimates. The average annual prevalence of disability among women over the same period is 7.4 percent using the CPSbased estimates, and 10.4 percent using the NHIS-based estimates. As can be seen in Figure 2, the NHIS-based estimates of the prevalence of disability are higher than the CPS-based estimates for both men and women, in every year. ${ }^{7}$ These differences are statistically significant in most years of our study. ${ }^{8}$

What is most important for our study, however, are not differences in the level of disability prevalence in the two data sets, but rather, the extent to which the trends in prevalence observed

${ }^{7}$ One explanation for the difference in the level of reported disability prevalence in the CPS and NHIS is the location of the work-limitations question in the two surveys. In the CPS, this question is asked in a section of the survey focusing on employment; in the NHIS it is asked as part of the basic health and demographic "core" questionnaire. To the extent that individuals already focused on questions about their health would be more apt to disclose any worklimitations, the NHIS would pick up a higher rate of reported disability.

${ }^{8}$ See Appendix Table 1 for the complete set of prevalence rates (and their standard errors) expressed in the figure. Statistical tests were t-tests of the differences in two proportions. 
Business Cycles and People with Disabilities-7

in the CPS are similar to those observed in the NHIS. To test whether the trends in disability prevalence between 1983 and 1996 are statistically similar in both data sets, we regress the prevalence of disability in the CPS and NHIS (pooled sample) on a dummy variable, indicating whether the prevalence estimate comes from the CPS or NHIS data, a higher-order polynomial time-trend, and the interactions of the time trend and the indicator variables. We then test the joint significance of the interaction terms using an F-test. Based on this method, we find no difference, at conventional levels of significance, between the time-series patterns of disability prevalence for men and women in the two data sets. (See Appendix Table 4, columns 1-2, for the results of these tests and Burkhauser, Houtenville, and Nargis 2001 for a more complete description of our test methodology.)

Key Economic Variables

Employment. The analysis focuses on the role that employment plays in the household income of men and women with disabilities. Individuals who report that they work more than 52 hours per year are considered employed. ${ }^{9}$ Individuals with fewer than 52 work hours annually are considered detached from the labor market. ${ }^{10}$ Annual labor earnings include income from all market sources, including primary and secondary jobs and self-employment income. Based on this definition we calculate employment rates for those with and without disabilities for both the CPS and NHIS data.

\footnotetext{
${ }^{9}$ Annual hours are calculated by multiplying the number of weeks worked by average hours worked per week. While our annual definition of employment is somewhat arbitrary, our results are not sensitive to the hours cutoff we chose.

${ }^{10}$ This category includes individuals who are out of the labor force and individuals who are long-term unemployed (i.e., did not work during the measurement year).
} 
Business Cycles and People with Disabilities-8

Household Income. Although we primarily are concerned with the economic status of individuals, we recognize that most people share resources with other coresident individuals and have access to income that does not flow directly to them (this is particularly important for spouses who do not work in the marketplace). Most researchers agree that the income-sharing unit should be broader than the individual, but there remains the issue of precisely who should be included in it. Some United States income distribution scholars have defined the unit as encompassing people related by blood or marriage who co-reside, i.e., the CPS family-sharing unit definition (see, for example, Karoly 1993 and Karoly and Burtless 1995). Others use the broader household-based common residence definition. ${ }^{11}$

In this study, we use the CPS household-sharing unit definition. We define household income as the sum of all pre-tax, post-transfer income received by individuals residing in a single residence. ${ }^{12,13}$ To account for the fact that $\$ 500$ a week provides a higher standard of living for a single-person household than it does for individuals belonging to larger households, we adjust household income by an equivalence factor. Since there is no universally accepted scale, we assume an elasticity with respect to household size of $0.5 .{ }^{14}$ In the CPS the income values are for

\footnotetext{
${ }^{11}$ Atkinson, Rainwater, and Smeeding (1995) and Burkhauser, Crews and Daly (1997) argue that using the family definition, rather than the less restrictive household-based definition, produces a bleaker picture of the income distribution because it treats a larger number of individuals as single-person households even when they reside with and share the benefits of living with others. sources.

${ }^{12}$ In the CPS data, income includes all cash income received from private and public

${ }^{13}$ The CPS data do not provide net-of-tax income information.

${ }^{14}$ An equivalence scale with an elasticity of 1 (the per capita scale) implies no economies of scale in shared living. An equivalence scale with an elasticity of 0 (i.e., no adjustments for household size) implies an infinite number of individuals can live equally well on a given household income. An elasticity of 0.5 falls between these two options and also is close to the assumptions about economies of scale implicit in the U.S. Bureau of Census poverty scales
} 
Business Cycles and People with Disabilities—9

the year prior to the survey year. Thus, we use CPS data for 1981, 1990, and 2000 to track

income in 1980, 1989, and 1999. Because we are comparing income across years, we adjust income using the Consumer Price Index for all Urban Consumers (CPI-U); all income values are in 1998 dollars. Due to limitations in the NHIS income questions, we calculate household income only for the CPS sample. ${ }^{15}$

Government Transfer Receipt. An important component of income for many individuals with disabilities is government-provided transfers. Throughout this study transfers are classified in two ways: individually-based and disability-related (disability benefits) and household-based and of any type or form (public transfers). Disability benefits include income from Workers' Compensation, the Social Security Disability Insurance Program, Veterans Benefits, and Supplemental Security Income. Public transfers include all cash benefits not specifically related to health.

\section{Adjusting for CPS Topcoding}

To maintain the anonymity of the survey respondents, the CPS topcodes most sources of income. Topcodes differ by income source and change over time (i.e., the portion of the distribution affected varies over time and across income sources.) To ensure that such changes in topcoding rules are not systematically affecting our results, we follow other CPS users (Daly and Valletta 2000; Karoly 1993; Karoly and Burtless 1995) and adjust the data. The adjustment we

(Burkhauser, Smeeding, and Merz 1996).

${ }^{15}$ The NHIS income questions ask respondents to identify the income bracket for their household. While such bracketed information provides a rough approximation of the economic well-being of a household it does not allow us to make precise calculations of changes in household income over time or to compare the NHIS income values to those from the more detailed CPS. (See Burkhauser, Houtenville, and Nargis (2001) for a discussion of these issues and an attempt to impute household income values for NHIS sample members.) 
Business Cycles and People with Disabilities-10

employ imposes the harshest annual topcode across all years for each income source, so that each source of income is topcoded at the same point in the distribution for each year in our sample. ${ }^{16}$ Sample Definition

Our examination focuses on the experiences of working-age men and women aged 25 to 61. This limited age range avoids confusing reductions in work or household income associated with disability with reductions or declines associated with retirement at older ages or initial transitions in and out of the labor force related to job shopping at younger ages. Men and women in the Armed Forces are excluded from our analysis. With these sample restrictions we have an average of 72,000 working-age men and women in the CPS and 50,000 working-age men and women in the NHIS. The sample of respondents with disabilities averages 9,500 in the CPS and 5,000 in the NHIS. All of our analysis are weighted by the individual sampling weights provided by the respective surveys.

\section{Business Cycle Dating}

To trace economic outcomes of people with disabilities over the business cycle we focus on three years representing peak or near peak points—1980, 1989, and 1999—and two years representing trough points_-1982 and 1991. An ideal analysis would make peak to peak comparisons $(1979,1989$, and the next business cycle peak). However, data constraints limit the choice of years compared to 1980 (the first year of data with disability information), 1989 (the peak of the 1980s business cycle), and 1999 (the latest year of data available).

\footnotetext{
${ }^{16}$ For some sources of income, the level of detail changes over time. In this case, we aggregate the detailed data such that we have consistently defined variables over time. We impose the topcode solution described above on the aggregated sources by assuming the topcode is the sum of the topcodes imposed on each of the component sources.
} 
Business Cycles and People with Disabilities-11

\section{Economic Outcomes of People with Disabilities over the Business Cycle}

\section{Employment}

Business cycles have a powerful effect on household income because they forcefully reduce employment. Table 1 shows the sensitivity of employment rates to economic fluctuations over the past 20 years for working-age men and women with and without disabilities. ${ }^{17}$ As the table shows, during the 1980s the employment of men with and without disabilities was procyclical, falling with recession and rising with recovery. In 1980, the first year the economy began to slow, employment rates of men with and without disabilities were relatively high -42.6 percent and 96.7 percent, respectively. Employment for men with and without disabilities declined as the economy moved through a recession, declining by about 2 percent for each group. Economic recovery once again boosted employment rates among men, particularly those with disabilities. Between 1982 and 1989, the employment rate among men with disabilities rose 5.1 percent, surpassing the 1980 peak. Tests for differences in the levels and trends in employment between men with and without disabilities during the 1980s show a significant difference in the level of employment between men with and without disabilities, but no significant difference in the trends. $^{18}$

In the 1990s, the employment experiences of men with and without disabilities began to diverge. For men without disabilities, the familiar procyclical pattern continued; employment fell

\footnotetext{
${ }^{17}$ Employment rates (and standard errors) for each year of our sample are reported in Appendix Table 2.

${ }^{18}$ Tests performed were analogous to those conducted for differences in trends in disability prevalence across data sources (i.e., differences in levels were tested using t-tests of the differences in two proportions; differences in trends were tested using a simple regression model of employment and a higher-order polynomial time-trend.) Results of the trend tests are reported in Appendix Table 5.
} 
Business Cycles and People with Disabilities-12

as the economy moved into recession in the early 1990s but rebounded over the next seven years of economic growth (1992 to 1999). By 1999, the last year of available CPS data, the employment of men without disabilities was near its 1989 peak level. In contrast, the employment pattern of men with disabilities was quite different over the 1990s. Employment rates among men with disabilities fell as the economy moved into recession, but then continued to fall during the expansion, when job growth was substantial and the employment of men without disabilities was rising. By 1999 the employment rate of working-age men with disabilities had not only failed to return to its 1989 level but was substantially below its 1992 trough year level. Overall, between 1989 and 1999, the employment rate of men with disabilities fell from 43.9 to 33.9 percent, a decline of more than 25 percent. Consistent with Table 1, separate statistical tests show significant differences in both the level of employment between men with and without disabilities and in their trends. (See Appendix Table 5 for these results.)

The story for women is similar. The employment of women with and without disabilities was constant in the early recession years of the 1980s business cycle and then increased substantially through the growth years that followed. However, as was the case for men, over the 1990s business cycle the employment experience of women with and without disabilities began to diverge. For women without disabilities, employment remained near its 1989 peak through the recession years of the early 1990s and grew thereafter. In contrast, the employment rate of women with disabilities fell as the economy moved into recession and continued to fall even over the recovery period. Statistical tests confirm that while there is a significant difference in the level of employment rates over the entire period, there is no significant difference in the employment 
Business Cycles and People with Disabilities—13

trends for women with and without disabilities in the 1980s. In contrast, and as for the sample of men, there is a significant difference in employment trends in the 1990s. (See Appendix Table 5.)

To ensure that these employment patterns are not an artifact of the CPS data or a result of changes in the composition of the population with disabilities, we perform two robustness checks. To address the first concern we compare the CPS employment trends to those found in the NHIS. In general, the trends in the NHIS data for the period 1983-1996 reinforce the employment trends reported for men and women with disabilities found in the CPS. That is, employment rates for men and women with disabilities were procyclical during the 1980s and countercyclical during the 1990s expansion. Testing for differences in employment trends across the two data sources we find no significant differences in the estimated trends from the CPS and NHIS. (See Appendix Table 4, columns 3-4, for results from these tests.)

To test for the possibility that changes in the composition of the population reporting a work disability are driving the results, we perform a simple shift-share analysis, controlling first for changes in age, race, education, and household size, and then controlling for these demographic changes and changes in employment rates. The results of these analyses, reported in Appendix Table 6, show that if the composition of the population with disabilities was the same in 1999 as it was in 1980 or 1989 (in terms of age, race, education, and household size), the economic outcomes for those with disabilities would be worse than the ones actually found in the data. This suggests that our results are not an artifact of demographic shifts, but rather the result of changing outcomes for those with disabilities. 


\section{Household Income and Its Sources}

For most people of working age, labor income is the principal source of household income. Thus, changes in the employment patterns of working-age men and women with disabilities potentially have a large impact on both their absolute and relative economic well-being. Table 2 shows median household size-adjusted income for men and women with and without disabilities. ${ }^{19}$ The median man with and without a disability gained over the 1980s business cycle. However, for men with disabilities, the gains were much less pronounced. For example, between 1980 and 1989, household size-adjusted income for the median man with a disability increased by 1.0 percent, compared to an increase of 9.8 percent for the median man without a disability.

In general, the same trends in median household size-adjusted income observed during the 1980s hold for the 1990s. The median man with and without disabilities gained during the period, but men without disabilities gained far more. The trends for the median woman with disabilities were similar in the 1980s. During the 1990s, growth in household income for the median woman with a disability kept pace with that of the median woman without a disability.

The contrast between the trends in employment and household income among those with disabilities suggest that the households of working-age people with disabilities relied far more on nonlabor sources of income during the 1990s than during the 1980s. Table 3 provides a more detailed look at the various sources of household income of our four groups and how they changed over the past two decades. Mean real household income is divided into five components—own labor earnings, the labor earnings of other household members, own public

\footnotetext{
${ }^{19}$ Estimates for each year of the sample are reported in Appendix Table 3.
} 
Business Cycles and People with Disabilities—-15

disability transfers, all other sources of public transfers, and all other sources of household income. The sum of the means of these five income sources equals mean household income. ${ }^{20}$

There was a general decline in the share of household income contributed by men over the entire period, but the decline in the share contributed by men with disabilities during the 1990s business cycle far exceeded the slight decline by men without disabilities. For example, the share of household income contributed by men without disabilities fell from 66.7 percent in 1980 to 62.3 percent in 1989, a decline of 6.8 percent. Between 1989 and 1999 there was very little change in their share. The patterns for men with disabilities are quite different. Between 1980 and 1989 the share of household income contributed by men with disabilities fell from 23.0 percent in 1980 to 22.2 percent in 1989 , a decline of 3.5 percent, or about one-half of the percentage drop experienced by men without disabilities. In contrast, between 1989 and 1999 the earnings share of household income contributed by men with disabilities fell 26.5 percent, to 17.0 percent.

As the share of household income coming from the labor earnings of men with and without disabilities declined, the share coming from labor earnings of other family members increased. However, the increase in the share of labor earnings coming from other family members was larger in the households of men without disabilities than of men with disabilities. As a result, over the past 20 years the households of men with disabilities have become increasingly reliant on non-labor sources of income.

\footnotetext{
${ }^{20}$ All negative sources of income were converted to zero in the calculation of income shares. Means rather than medians were used and no adjustments were made in household size to allow the individual sources of income reported in Table 3 to sum to the total.
} 
Business Cycles and People with Disabilities-16

The results for women are somewhat different. Over the 1980s business cycle, the share of household income contributed by women with and without disabilities increased substantially. This trend continued over the 1990s business cycle for women without disabilities, but reversed for women with disabilities. As a result, in 1999 earnings of women without disabilities accounted for 38.2 percent of their household income; for women with disabilities this share was 14.1 percent.

As the share of household income from labor earnings declined for men and women with disabilities, the share coming from public disability-related transfers increased. This substitution is particularly evident in the 1990s. Among men with disabilities, the share of household income coming from public disability transfers increased by 35.1 percent between 1989 and 1999; women with disabilities experienced a similar increase, 31.6 percent during the period. ${ }^{21}$ The share of household income coming from all other public transfers declined steadily during the 1990s for all four groups. All other sources of household income fell during the peak-to-trough years in the 1990s and rose thereafter for all groups. However, over the entire period these sources fell for all groups.

\section{Gains in Household Income across the Distribution}

Figure 3 looks behind the profile of the median man and woman with and without a disability_examined in Table 2 - and reports changes in real household size-adjusted income across the entire income distribution. Figure 3 shows the dollar difference in real household size-

\footnotetext{
${ }^{21}$ Elsewhere we show that the increase in real public disability transfers over the 1990s came primarily from rapid growth in the value of SSI and SSDI benefits; in contrast, Workers' Compensation and Veterans' Benefits fell in real terms over the period (Burkhauser, Daly, and Houtenville 2001).
} 
Business Cycles and People with Disabilities-17

adjusted income by percentile of the income distribution for men and women with and without disabilities between 1980 and 1989, and between 1989 and 1999. Each line cuts the horizontal axis at the percentile at which real income in one-year equals real income in the other. Values above (below) the horizontal axis show that mean real income in that percentile increased (decreased) over the period.

In contrast to the population of men without disabilities, which gained across nearly the entire income distribution over both business cycles, within the population of men with disabilities the experiences varied with the level of household income and across business cycles (Figure 3, panels $\mathrm{A}$ and B). In both periods examined, the lower part of the household size-adjusted distribution experienced only modest changes in income, with small declines during the 1980s and small gains during the 1990s. Declines in own labor earnings in this part of the distribution were for the most part offset by increases in disability-related transfers. The primary difference between the two periods for the population of men with disabilities occurred in the upper half of the income distribution. Over the 1980s business cycle all percentiles in the upper part of the distribution gained. In contrast, over the 1990s business cycle, incomes in the middle of the distribution (between the $50^{\text {th }}$ and $65^{\text {th }}$ percentiles) remained flat, exhibiting no more growth than those in the bottom half of the income distribution. It is not until the $75^{\text {th }}$ percentile and above that income increased by the same magnitude as in the 1980s. Declines in own labor earnings in the middle of the distribution during the 1990s were only partially offset by increases in disabilityrelated transfer income.

We find the same patterns for women with and without disabilities (Figure 3, panels $\mathrm{C}$ and D). Women without disabilities gained across the entire distribution in both business cycles. For 
Business Cycles and People with Disabilities-18

women with disabilities the lower part of the distribution experienced almost no change in income over the 1980s business cycle, while the top 50 percent of the distribution gained. In contrast, during the 1990s business cycle, incomes rose at all levels of the distribution, although by relatively small amounts. Only those in the top $25^{\text {th }}$ percentile gained, and for the most part their gains were modest.

\section{Conclusions and Issues for Future Research}

We examined the relative responsiveness of employment and household income of working-age men and women to business cycle fluctuations over the past two decades. Overall, the results indicate that during the 1980 s, economic outcomes for those with and without disabilities were procyclical, falling during recessionary years and rising during years of expansion. In contrast, the employment of working-age men and women with disabilities fell continuously over the 1990s. While a substantial increase in disability transfer income in the 1990s replaced a significant fraction of the lost labor earnings, it did not prevent most of the households of men and women with disabilities from losing economic ground relative to the rest of the population.

Recognizing that CPS data are not the ideal source of information about persons with disabilities, we checked the robustness of our results using data from the NHIS. While disability prevalence and employment rates found in the CPS data for this population are significantly different from those found in the NHIS data, there is no significant difference between the trends in prevalence or employment found in these data sources. Hence we argue that the unprecedented decline in the importance of work as a source of household income among 
working-age men and women with disabilities in the 1990s is not an artifact of the CPS data but a real and important phenomenon.

These results suggest that recent studies documenting the decline in the relative employment of men with disabilities in the 1990s cannot be dismissed out of hand. So far, two major hypotheses have been proposed to explain this decline. Acemoglu and Angrist (1998), using CPS data from 1988 to 1997, report employment patterns similar to those reported here and argue that this decline was caused by unintended consequences of the passage of the Americans with Disabilities Act of 1990 (ADA). ${ }^{22}$ Bound and Waidmann (2000), using CPS data from 1989 to 1999 , also report employment patterns similar to those reported here but argue that increases in Social Security Disability Insurance benefit rolls can account for all of the decline in employment of working-age men with disabilities during this period. So far, however, no studies have been able to satisfactorily disentangle the impact of demand side factors related to the passage of the ADA or changes in the mix of jobs in the economy in the 1990s from supply side factors related to changes in the ease of access to SSDI and SSI benefits or to a reduction in the share of jobs that provide private health insurance, which would discourage work among the population with disabilities. Pinning down the magnitudes of the various effects is the next necessary step to fully understanding the causes of the recent decline in employment among those with disabilities and developing policies targeted at reversing this trend.

\footnotetext{
${ }^{22}$ DeLeire (2000) using data from the Survey of Income and Program Participation for the years 1990-1994 reports similar findings and proposes the same explanation. Kruse and Schur (2000) use these same data but finds that employment trends of working-age men with disabilities are sensitive to one's choice of disability measure.
} 
Business Cycles and People with Disabilities—20

\section{References}

Acemoglu, Daron and Joshua Angrist. 1998. “Consequences of Employment Protection? The Case of the Americans with Disabilities Act.” NBER Working Paper No. W6670. Cambridge, MA: National Bureau of Economic Research.

Atkinson, Anthony, B., Lee Rainwater and Timothy M. Smeeding. 1995. Income Distribution in OECD Countries: Evidence from the Luxembourg Income Study (LIS), Social Policy Studies No. 18. Paris: OECD.

Blackburn, McKinley and David Bloom. 1989. "Income Inequality, Business Cycles, and Female Labor Supply." In Research on Economic Inequality, Volume 1. Greenwich, CT and London: JAI Press, pp. 327-342.

Blank, Rebecca and David Card. 1993. "Poverty, Income Distribution, and Growth: Are They Still Connected?" Brookings Papers on Economic Activity, Vol. 2. Washington, DC: Brookings Institution Press, pp. 285-339.

Bound, John and Richard V. Burkhauser. 2000. "Economic Analysis of Transfer Programs Targeted on People with Disabilities." In Handbook of Labor Economics, Vol. 3. Edited by Orley Ashenfelter and David Card. New York, Amsterdam?: Elsevier Science, pp. 3417-3528.

Bound, John and Timothy Waidmann. 2000. “Accounting for Recent Declines in Employment Rates among the Working-Aged Disabled." NBER Working Paper No. W7975. Cambridge, MA: National Bureau of Economic Research.

Burkhauser, Richard V., Mary C. Daly, and Andrew Houtenville. 2001. "How Working-Age People with Disabilities Fared over the 1990s Business Cycle." In Ensuring Health and Income Security for an Aging Workforce. Edited by P. Budetti, R.V. Burkhauser, J. Gregory, and A. Hunt. Kalamazoo, MI: W.E. Upjohn Institute for Employment Research, pp. 291-346.

Burkhauser, Richard V. and Mary C. Daly. 1996. "Employment and Economic Well-Being Following the Onset of a Disability: The Role for Public Policy." In Disability, Work, and Cash Benefits, Jerry Mashaw, Virginia Reno, Richard V. Burkhauser, and Monroe Berkowitz, eds. Kalamazoo, MI: W.E. Upjohn Institute for Employment Research, pp. 59-102.

Burkhauser, Richard V., Amy D. Crews, Mary C. Daly, and Stephen P. Jenkins. 1999. “Testing the Significance of Income Distribution Changes over the 1980s Business Cycle: A CrossNational Comparison." Journal of Applied Econometrics 14, pp. 253-272.

Burkhauser, Richard V. Amy D. Crews and Mary C. Daly. 1997. "Recounting Winners and Losers in the 1980s: A Critique of Income Distribution Measurement Methodology." Economics Letters 54 (May): 35-40.

Burkhauser, Richard V., Andrew Houtenville, and Niger Nargis. 2001. "Comparisons of Time Trends from Two Data Sources.” Economics of Disability Research Report No. 4. Ithaca, NY: Cornell University, Rehabilitation Research Center. 
Business Cycles and People with Disabilities—21

Burkhauser, Richard V., Timothy M. Smeeding and Joachim Merz. 1996. "A Relative Inequality and Poverty in Germany and the United States Using Alternative Equivalency Scales." The Review of Income and Wealth 42(4): 381-400.

Daly, Mary C., Greg Duncan, Peggy McDonough, and David Williams. 1999 "Optimal Indicators of Socioeconomic Status for Health Research.” Working Paper, 99-03. San Francisco: Federal Reserve Bank.

Daly, Mary C. and Robert Valletta. 2000. "Inequality and Poverty in the United States: The Effects of Changing Family Behavior and Rising Wage Dispersion." Working Paper 2000-06. San Francisco: Federal Reserve Bank.

DeLeire, Thomas. 2000. "The Wage and Employment Effects of the Americans with Disabilities Act." Journal of Human Resources 35(4): 693-715.

Hoynes, Hilary. 2000. “The Employment, Earnings, and Income of Less Skilled Workers over the Business Cycle.” NBER Working Paper 7188. Cambridge, MA: National Bureau of Economic Research.

Kirchner, Corinne. 1996. "Looking Under the Street Lamp: Inappropriate Uses of Measures Just Because They are There." Journal of Disability Policy Studies 7(1): 77-90.

Karoly, Lynn A. 1993 “The Trend in Inequality Among Families, Individuals, and Workers in the United States: A Twenty-Five Year Perspective." In Uneven Tides: Rising Inequality in America, edited by Sheldon Danziger and Peter Gottschalk. New York: Russell Sage Foundation.

Karoly, Lynn A. and Gary Burtless. 1995. "Demographic Change, Rising Earning Inequality, and the Distribution of Personal Well-Being, 1959-1989." Demography 32(3): 379-406.

Kruse, Douglas and Lisa Schur. 2000. "Employment of People with Disabilities Following the ADA." Mimeo, School of Management and Labor Relations. New Brunswick, NJ: Rutgers University.

Mashaw, Jerry and Virginia Reno. 1996. Balancing Security and Opportunity: the Challenge of Disability Income Policy. Report of the Disability Policy Panel, National Academy of Social Insurance, Washington, DC.

Myers, Robert. 1982. "Why Do People Retire from Work Early?” Aging and Work 5:83-91.

Myers, Robert. 1983. "Further Controversies on Early Retirement Study." Aging and Work 6: 105-109.

Robert, Stephanie and James S. House. 1996. "SES Differentials in Health by Age and Alternative Indicators of SES." Journal of Aging and Health 8(3): 359-388.

Smith, James P. and Raynard Kington. 1996. "Demographic and Economic Correlates of Health in Old Age." Document Number DRU-1316-NIA. Santa Monica, CA: RAND. 
Figure 1. Disability Prevalence by Household Size-Adjusted Income Decile
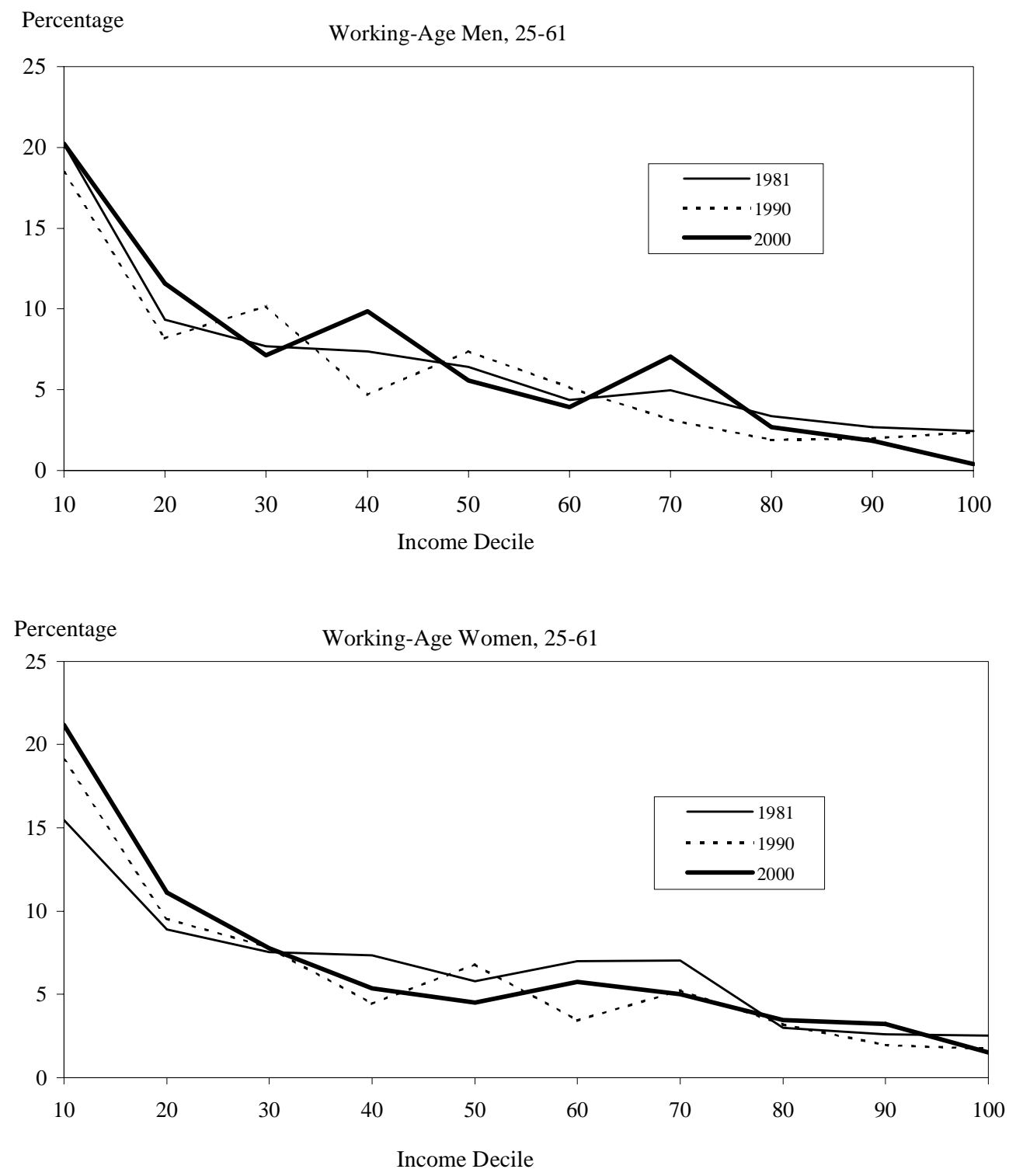

Source: Authors' calculations based on the March Current Population Survey, 1981, 1990, 2000. 
Figure 2. Disability Prevalence Among Working Age Individuals
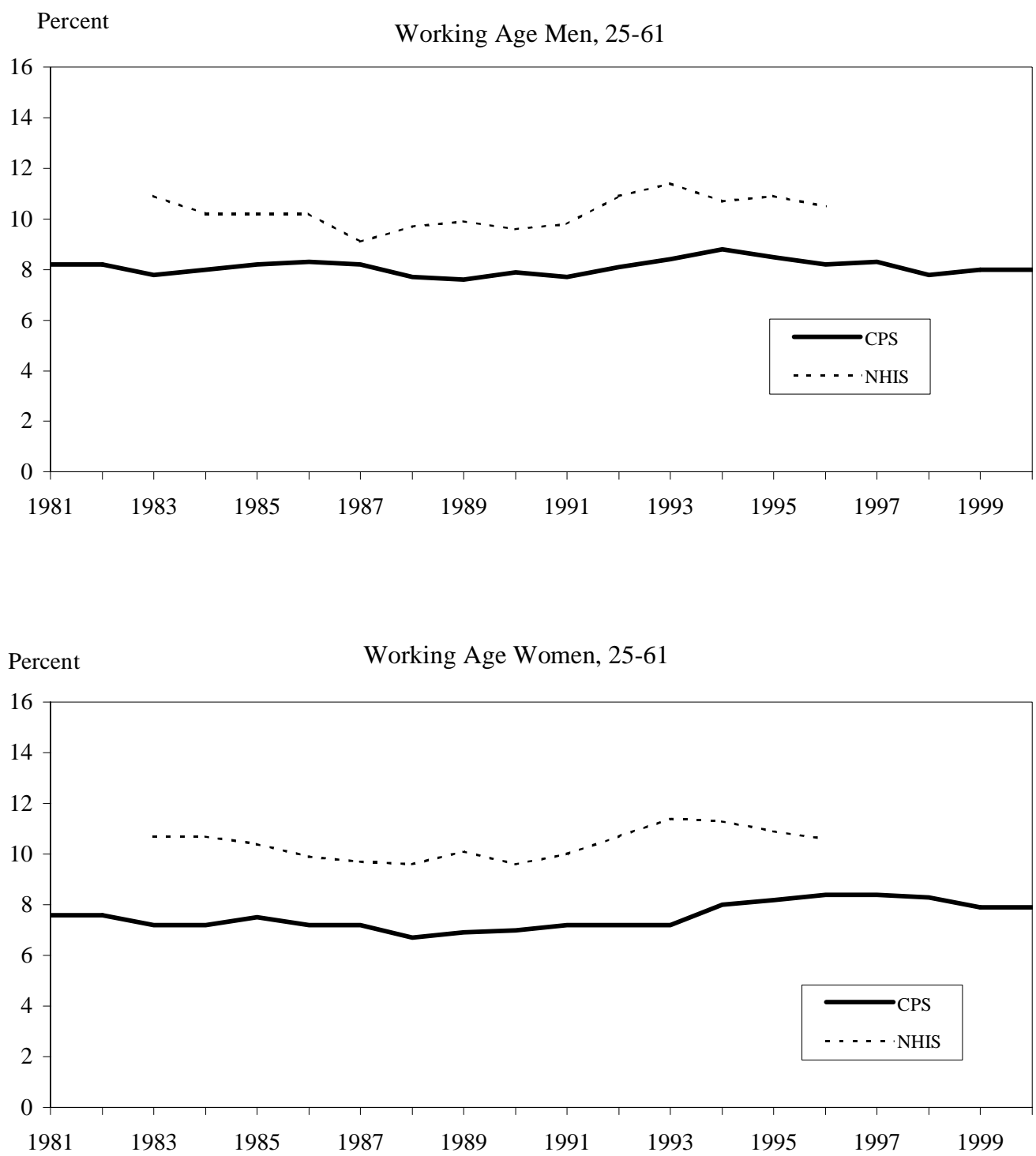

Source: Authors' calculations based on the March Current Population Survey, 1981-2000, and the National Health Interview Survey 1983-1996. 
Business Cycles and People with Disabilities—24

Figure 3. Change in Household Size-Adjusted Real Income, 1980-1989, and 1989-1998, by Percentile
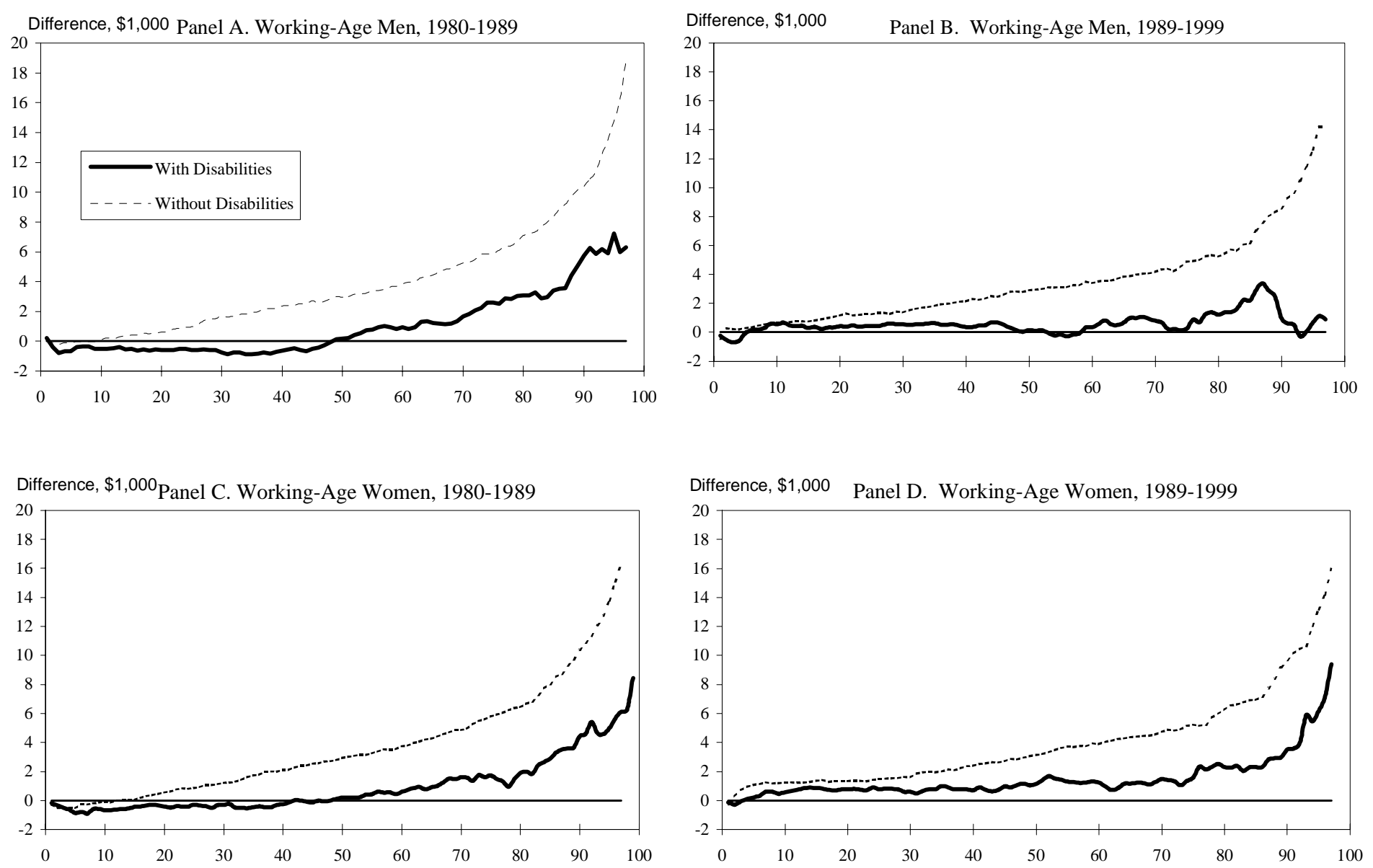

Source: Authors' calculations based on March CPS, 1981, 1990, 2000. 
Business Cycles and People with Disabilities—25

Table 1. Employment Rates of Working-Age Men and Women

by Disability Status

\begin{tabular}{|c|c|c|c|c|c|}
\hline \multirow[t]{3}{*}{ Work Year } & \multicolumn{2}{|c|}{ Employment Rate } & Change Years & \multicolumn{2}{|c|}{ Percentage Change } \\
\hline & \multicolumn{5}{|c|}{ Men } \\
\hline & $\begin{array}{c}\text { With } \\
\text { Disabilities }\end{array}$ & $\begin{array}{c}\text { Without } \\
\text { Disabilities }\end{array}$ & & $\begin{array}{c}\text { With } \\
\text { Disabilities }\end{array}$ & $\begin{array}{c}\text { Without } \\
\text { Disabilities }\end{array}$ \\
\hline & & & $1980-1982$ & -2.1 & -1.8 \\
\hline 1980 & 42.6 & 96.7 & 1982-1989 & 5.1 & 1.0 \\
\hline 1982 & 41.7 & 95.0 & 1980-1989 & 3.0 & -0.7 \\
\hline 1989 & 43.9 & 96.0 & 1989-1992 & -5.4 & -1.4 \\
\hline 1992 & 41.6 & 94.7 & 1992-1999 & -20.4 & 0.4 \\
\hline \multirow[t]{3}{*}{1999} & 33.9 & 95.1 & 1989-1999 & -25.7 & -0.9 \\
\hline & \multicolumn{5}{|c|}{ Women } \\
\hline & $\begin{array}{c}\text { With } \\
\text { Disabilities }\end{array}$ & $\begin{array}{c}\text { Without } \\
\text { Disabilities }\end{array}$ & & $\begin{array}{c}\text { With } \\
\text { Disabilities }\end{array}$ & $\begin{array}{c}\text { Without } \\
\text { Disabilities }\end{array}$ \\
\hline & & & $1980-1982$ & -3.0 & -3.3 \\
\hline 1980 & 28.5 & 69.2 & 1982-1989 & 4.5 & 14.0 \\
\hline 1982 & 29.3 & 69.2 & 1980-1989 & 1.5 & 10.7 \\
\hline 1989 & 37.4 & 77.0 & 1989-1992 & -10.6 & -3.4 \\
\hline 1992 & 34.2 & 77.6 & 1992-1999 & 17.9 & 13.7 \\
\hline 1999 & 33.3 & 81.5 & 1989-1999 & 7.3 & 10.3 \\
\hline
\end{tabular}

Source: Authors' calculations based on the March Current Population Survey, 1981-2000. 
Business Cycles and People with Disabilities—26

Table 2. Median Household Size-Adjusted Real Income of Working-Age Men and Women by Disability Status

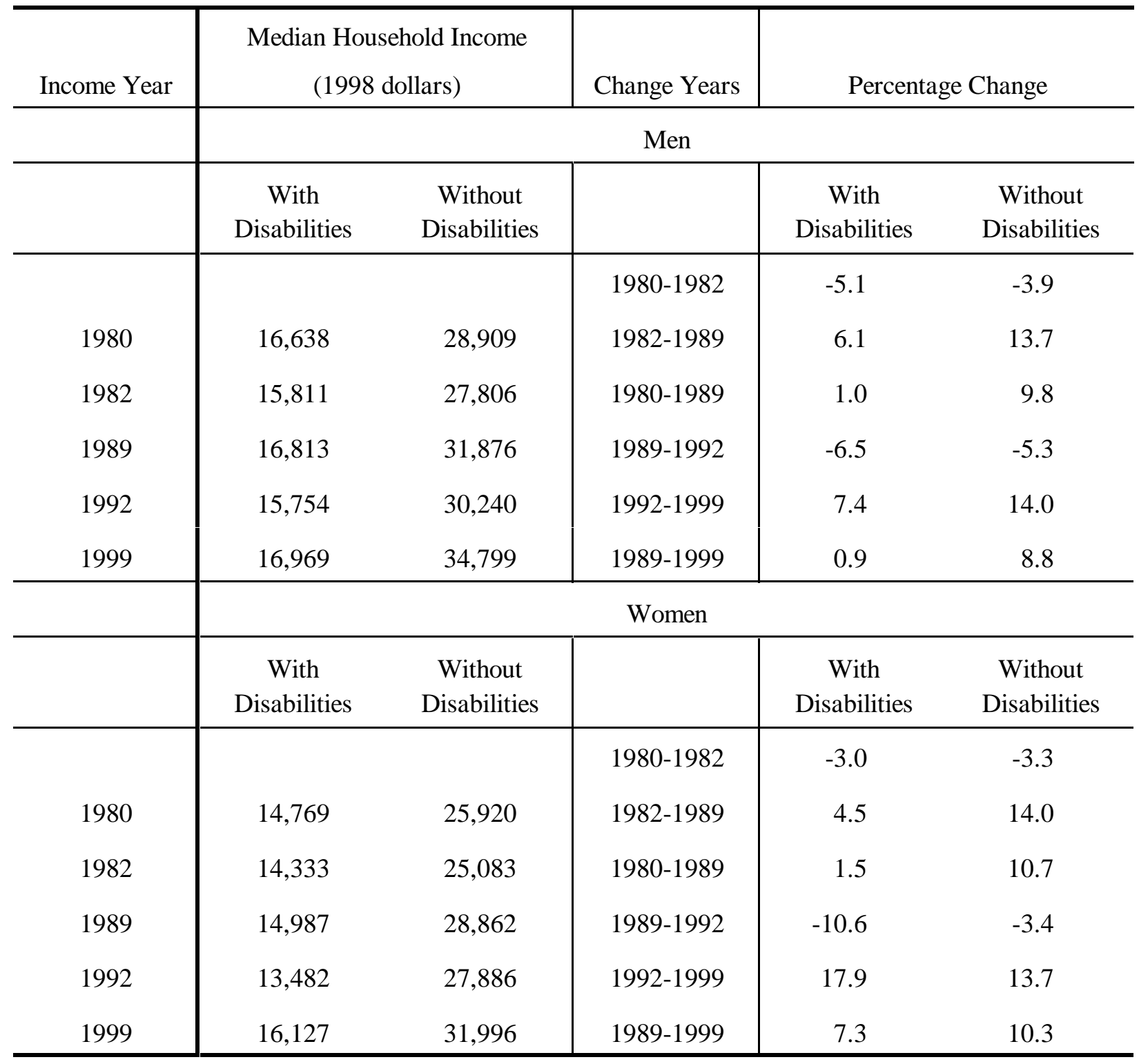

Source: Authors' calculations based on the March Current Population Survey, 1981-2000. 
Table 3. Share of Household Income by Source for Working-Age Men and Women

\section{by Disability Status}

\begin{tabular}{|c|c|c|c|c|c|c|c|c|c|c|}
\hline \multicolumn{11}{|c|}{ Men } \\
\hline & \multicolumn{2}{|c|}{ Own Earnings } & \multicolumn{2}{|c|}{$\begin{array}{l}\text { Earnings of Other } \\
\text { Household Members }\end{array}$} & \multicolumn{2}{|c|}{$\begin{array}{c}\text { Own Public } \\
\text { Disability Transfers }\end{array}$} & \multicolumn{2}{|c|}{$\begin{array}{l}\text { All Other } \\
\text { Public Transfer }\end{array}$} & \multicolumn{2}{|c|}{$\begin{array}{c}\text { All Other } \\
\text { Household Income }\end{array}$} \\
\hline & \multicolumn{10}{|c|}{ Percent Shares } \\
\hline Income Year & $\begin{array}{c}\text { With } \\
\text { Disabilities }\end{array}$ & $\begin{array}{c}\text { Without } \\
\text { Disabilities }\end{array}$ & $\begin{array}{c}\text { With } \\
\text { Disabilities }\end{array}$ & $\begin{array}{c}\text { Without } \\
\text { Disabilities }\end{array}$ & $\begin{array}{c}\text { With } \\
\text { Disabilities }\end{array}$ & $\begin{array}{c}\text { Without } \\
\text { Disabilities }\end{array}$ & $\begin{array}{c}\text { With } \\
\text { Disabilities }\end{array}$ & $\begin{array}{c}\text { Without } \\
\text { Disabilities }\end{array}$ & $\begin{array}{c}\text { With } \\
\text { Disabilities }\end{array}$ & $\begin{array}{c}\text { Without } \\
\text { Disabilities }\end{array}$ \\
\hline 1980 & 23.0 & 66.7 & 25.8 & 22.6 & 15.1 & 0.2 & 20.9 & 3.9 & 14.2 & 6.3 \\
\hline 1982 & 21.6 & 63.4 & 26.2 & 24.0 & 14.8 & 0.2 & 22.0 & 5.1 & 14.5 & 7.0 \\
\hline 1989 & 22.2 & 62.3 & 28.2 & 27.4 & 16.0 & 0.2 & 19.9 & 3.4 & 13.0 & 6.4 \\
\hline 1992 & 19.1 & 60.2 & 29.4 & 28.3 & 18.7 & 0.3 & 20.6 & 5.0 & 11.6 & 5.9 \\
\hline 1999 & 17.0 & 61.3 & 30.1 & 28.8 & 22.8 & 0.4 & 16.4 & 3.1 & 12.1 & 6.0 \\
\hline Change Years & \multicolumn{10}{|c|}{ Percentage Change } \\
\hline $1980-82$ & -6.3 & -5.1 & 1.5 & 6.0 & -2.0 & 0.0 & 5.1 & 26.7 & 2.1 & 10.5 \\
\hline 1982-89 & 2.7 & -1.8 & 7.4 & 13.2 & 7.8 & 0.0 & -10.0 & -40.0 & -10.9 & -9.0 \\
\hline 1980-89 & -3.5 & -6.8 & 8.9 & 19.2 & 5.8 & 0.0 & -4.9 & -13.7 & -8.8 & 1.6 \\
\hline $1989-92$ & -15.0 & -3.4 & 4.2 & 3.2 & 15.6 & 40.0 & 3.5 & 38.1 & -11.4 & -8.1 \\
\hline 1992-99 & -11.6 & 1.8 & 2.4 & 1.8 & 19.8 & 28.6 & -22.7 & -46.9 & 4.2 & 1.7 \\
\hline 1989-99 & -26.5 & -1.6 & 6.5 & 5.0 & 35.1 & 66.7 & -19.3 & -9.2 & -7.2 & -6.5 \\
\hline
\end{tabular}


Business Cycles and People with Disabilities—28

Table 3 (continued)

\begin{tabular}{|c|c|c|c|c|c|c|c|c|c|c|}
\hline \multicolumn{11}{|c|}{ Women } \\
\hline & \multicolumn{2}{|c|}{ Own Earnings } & \multicolumn{2}{|c|}{$\begin{array}{l}\text { Earnings of Other } \\
\text { Household Members }\end{array}$} & \multicolumn{2}{|c|}{$\begin{array}{c}\text { Own Public Disability } \\
\text { Transfers }\end{array}$} & \multicolumn{2}{|c|}{ All Other Public Transfer } & \multicolumn{2}{|c|}{$\begin{array}{l}\text { All Other Household } \\
\text { Income }\end{array}$} \\
\hline \multirow[b]{2}{*}{ Income Year } & \multicolumn{10}{|c|}{ Percent Shares } \\
\hline & $\begin{array}{c}\text { With } \\
\text { Disabilities }\end{array}$ & $\begin{array}{c}\text { Without } \\
\text { Disabilities }\end{array}$ & $\begin{array}{c}\text { With } \\
\text { Disabilities }\end{array}$ & $\begin{array}{c}\text { Without } \\
\text { Disabilities }\end{array}$ & $\begin{array}{c}\text { With } \\
\text { Disabilities }\end{array}$ & $\begin{array}{c}\text { Without } \\
\text { Disabilities }\end{array}$ & $\begin{array}{c}\text { With } \\
\text { Disabilities }\end{array}$ & $\begin{array}{c}\text { Without } \\
\text { Disabilities }\end{array}$ & $\begin{array}{c}\text { With } \\
\text { Disabilities }\end{array}$ & $\begin{array}{c}\text { Without } \\
\text { Disabilities }\end{array}$ \\
\hline 1980 & 9.9 & 28.2 & 40.5 & 55.0 & 13.7 & 0.9 & 22.1 & 7.4 & 13.2 & 8.2 \\
\hline 1982 & 10.7 & 28.9 & 39.9 & 52.8 & 13.9 & 0.9 & 22.4 & 8.2 & 12.3 & 8.9 \\
\hline 1989 & 14.3 & 33.6 & 36.6 & 51.1 & 14.9 & 0.8 & 21.7 & 6.1 & 11.8 & 7.9 \\
\hline 1992 & 12.8 & 35.4 & 35.7 & 48.8 & 17.8 & 0.8 & 21.4 & 7.4 & 10.8 & 7.2 \\
\hline 1999 & 14.1 & 38.2 & 36.3 & 48.9 & 20.5 & 0.7 & 15.6 & 4.5 & 12.2 & 7.3 \\
\hline Change Years & \multicolumn{10}{|c|}{ Percentage Change } \\
\hline $1980-82$ & 7.8 & 2.5 & -1.5 & -4.1 & 1.4 & 0.0 & 1.3 & 10.3 & -7.1 & 8.2 \\
\hline $1982-89$ & 28.8 & 15.0 & -8.6 & -3.3 & 6.9 & -11.8 & -3.2 & -29.4 & -4.1 & -11.9 \\
\hline $1980-89$ & 36.4 & 17.5 & -10.1 & -7.4 & 8.4 & -11.8 & -1.8 & -19.3 & -11.2 & -3.7 \\
\hline 1989-92 & -11.1 & 5.2 & -2.5 & -4.6 & 17.7 & 0.0 & -1.4 & 19.3 & -8.8 & -9.3 \\
\hline 1992-99 & 9.7 & 7.6 & 1.7 & 0.2 & 14.1 & -13.3 & -31.4 & -48.7 & 12.2 & 1.4 \\
\hline 1989-99 & -1.4 & 12.8 & -0.8 & -4.4 & 31.6 & -13.3 & -32.7 & -30.2 & 3.3 & -7.9 \\
\hline
\end{tabular}

Source: Authors' calculations based on the March Current Population Survey, 1981-2000. 
Business Cycles and People with Disabilities—29

Appendix Table 1. Prevalence of Disability Among Working-Age Men and Women in the Current Population Survey (CPS) and National Health Interview Survey (NHIS)

\begin{tabular}{|c|c|c|c|c|c|c|c|c|}
\hline \multirow[b]{3}{*}{ Year } & \multicolumn{4}{|c|}{ Men } & \multicolumn{4}{|c|}{ Women } \\
\hline & \multicolumn{2}{|c|}{ CPS } & \multicolumn{2}{|c|}{ NHIS } & \multicolumn{2}{|c|}{ CPS } & \multicolumn{2}{|c|}{ NHIS } \\
\hline & Estimate & $\begin{array}{c}\text { Standard } \\
\text { Error }\end{array}$ & Estimate & $\begin{array}{c}\text { Standard } \\
\text { Error }\end{array}$ & Estimate & $\begin{array}{c}\text { Standard } \\
\text { Error }\end{array}$ & Estimate & $\begin{array}{c}\text { Standard } \\
\text { Error }\end{array}$ \\
\hline 1981 & 8.2 & 0.139 & 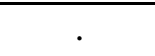 & • & 7.6 & 0.129 & • & • \\
\hline 1982 & 8.2 & 0.147 & . & . & 7.6 & 0.136 & . & . \\
\hline 1983 & 7.8 & 0.142 & 10.9 & 0.211 & 7.2 & 0.131 & 10.7 & 0.197 \\
\hline 1984 & 8.0 & 0.144 & 10.2 & 0.204 & 7.2 & 0.132 & 10.7 & 0.197 \\
\hline 1985 & 8.2 & 0.146 & 10.2 & 0.225 & 7.5 & 0.133 & 10.4 & 0.213 \\
\hline 1986 & 8.3 & 0.147 & 10.2 & 0.261 & 7.2 & 0.132 & 9.9 & 0.247 \\
\hline 1987 & 8.2 & 0.147 & 9.1 & 0.179 & 7.2 & 0.132 & 9.7 & 0.177 \\
\hline 1988 & 7.7 & 0.142 & 9.7 & 0.185 & 6.7 & 0.128 & 9.6 & 0.176 \\
\hline 1989 & 7.6 & 0.146 & 9.9 & 0.192 & 6.8 & 0.133 & 10.1 & 0.184 \\
\hline 1990 & 7.9 & 0.141 & 9.6 & 0.187 & 7.0 & 0.128 & 9.6 & 0.177 \\
\hline 1991 & 7.7 & 0.140 & 9.8 & 0.190 & 7.2 & 0.130 & 10.0 & 0.181 \\
\hline 1992 & 8.1 & 0.144 & 10.9 & 0.196 & 7.2 & 0.131 & 10.7 & 0.180 \\
\hline 1993 & 8.4 & 0.146 & 11.4 & 0.214 & 7.2 & 0.131 & 11.4 & 0.203 \\
\hline 1994 & 8.8 & 0.152 & 10.7 & 0.199 & 8.0 & 0.139 & 11.3 & 0.193 \\
\hline 1995 & 8.5 & 0.150 & 10.9 & 0.214 & 8.2 & 0.141 & 10.9 & 0.204 \\
\hline 1996 & 8.2 & 0.158 & 10.5 & 0.266 & 8.4 & 0.152 & 10.6 & 0.258 \\
\hline 1997 & 8.3 & 0.157 & . & . & 8.3 & 0.151 & . & . \\
\hline 1998 & 7.8 & 0.152 & . & r & 8.3 & 0.150 & . & . \\
\hline 1999 & 8.0 & 0.153 & . & . & 7.9 & 0.146 & . & . \\
\hline 2000 & 8.0 & 0.152 & & & 7.9 & 0.146 & 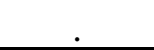 & \\
\hline
\end{tabular}

Source: Authors' calculations using the Current Population Survey (1981-2000) and National Health Interview Survey (1983-1996). 
Appendix Table 2. Employment Rates of Working Age Men and Women in the Current Population Survey (CPS) and National Health Interview Survey (NHIS), by Disability Status

\begin{tabular}{|c|c|c|c|c|c|c|c|c|}
\hline \multirow[b]{4}{*}{ Year } & \multicolumn{8}{|c|}{ Men } \\
\hline & \multicolumn{4}{|c|}{ Without Disabilities } & \multicolumn{4}{|c|}{ With Disabilities } \\
\hline & \multicolumn{2}{|c|}{$\mathrm{CPS}$} & \multicolumn{2}{|c|}{ NHIS } & \multicolumn{2}{|c|}{ CPS } & \multicolumn{2}{|c|}{ NHIS } \\
\hline & Estimate & $\begin{array}{c}\text { Standard } \\
\text { Error }\end{array}$ & Estimate & $\begin{array}{c}\text { Standard } \\
\text { Error }\end{array}$ & Estimate & $\begin{array}{c}\text { Standard } \\
\text { Error }\end{array}$ & Estimate & $\begin{array}{c}\text { Standard } \\
\text { Error }\end{array}$ \\
\hline 1980 & 96.7 & 0.889 & . & . & 42.6 & 0.094 & 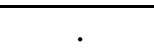 & . \\
\hline 1981 & 96.4 & 0.935 & . & $\cdot$ & 44.8 & 0.103 & $\cdot$ & . \\
\hline 1982 & 95.1 & 0.939 & . & . & 41.8 & 0.120 & . & . \\
\hline 1983 & 94.7 & 0.926 & 90.6 & 1.02 & 39.7 & 0.125 & 48.9 & 0.214 \\
\hline 1984 & 95.7 & 0.931 & 92.5 & 1.05 & 40.4 & 0.112 & 52.3 & 0.191 \\
\hline 1985 & 95.7 & 0.937 & 93.2 & 1.165 & 42.8 & 0.112 & 50.5 & 0.196 \\
\hline 1986 & 96.1 & 0.947 & 92.9 & 1.341 & 43.8 & 0.108 & 52.9 & 0.238 \\
\hline 1987 & 95.7 & 0.961 & 93.2 & 1.034 & 43.0 & 0.112 & 49.8 & 0.169 \\
\hline 1988 & 95.8 & 0.992 & 93.8 & 0.998 & 42.9 & 0.115 & 52.1 & 0.160 \\
\hline 1989 & 96.1 & 0.948 & 94.0 & 1.019 & 44.0 & 0.106 & 52.1 & 0.163 \\
\hline 1990 & 95.9 & 0.944 & 93.1 & 1.024 & 42.1 & 0.108 & 50.3 & 0.171 \\
\hline 1991 & 95.4 & 0.927 & 92.3 & 1.016 & 41.5 & 0.115 & 48.7 & 0.181 \\
\hline 1992 & 94.8 & 0.917 & 91.9 & 0.95 & 41.6 & 0.123 & 45.6 & 0.179 \\
\hline 1993 & 94.5 & 0.911 & 92.6 & 1.002 & 37.2 & 0.128 & 47.7 & 0.185 \\
\hline 1994 & 94.8 & 0.92 & 92.7 & 0.983 & 38.0 & 0.124 & 48.4 & 0.180 \\
\hline 1995 & 94.8 & 0.977 & 93.2 & 1.027 & 34.9 & 0.134 & 44.9 & 0.186 \\
\hline 1996 & 94.9 & 0.977 & 93.4 & 1.326 & 38.2 & 0.131 & 44.1 & 0.225 \\
\hline 1997 & 95.2 & 0.993 & . & . & 35.5 & 0.126 & . & . \\
\hline 1998 & 95.1 & 0.976 & . & . & 34.4 & 0.127 & . & . \\
\hline \multirow[t]{2}{*}{1999} & 95.2 & 0.953 & . & . & 34.0 & 0.125 & . & . \\
\hline & \multicolumn{8}{|c|}{ Women } \\
\hline 1980 & 69.3 & 0.795 & . & . & 28.5 & 0.234 & . & . \\
\hline 1981 & 69.9 & 0.832 & . & • & 28.1 & 0.244 & . & . \\
\hline 1982 & 69.3 & 0.867 & . & . & 29.3 & 0.244 & . & . \\
\hline 1983 & 70.7 & 0.868 & 64.7 & 0.908 & 28.9 & 0.240 & 31.3 & 0.326 \\
\hline 1984 & 72.6 & 0.863 & 66.8 & 0.925 & 30.2 & 0.234 & 33.4 & 0.321 \\
\hline 1985 & 73.1 & 0.905 & 69.3 & 1.018 & 32.5 & 0.235 & 33.6 & 0.345 \\
\hline 1986 & 74.4 & 0.911 & 70.8 & 1.26 & 32.1 & 0.231 & 37.3 & 0.402 \\
\hline 1987 & 75.2 & 0.942 & 71.3 & 0.914 & 33.9 & 0.228 & 36.5 & 0.289 \\
\hline 1988 & 76.7 & 0.979 & 72.2 & 0.937 & 36.2 & 0.231 & 37.5 & 0.282 \\
\hline 1989 & 77.0 & 0.931 & 72.9 & 0.947 & 37.5 & 0.219 & 40.5 & 0.290 \\
\hline 1990 & 77.6 & 0.909 & 73.5 & 0.953 & 34.9 & 0.217 & 40.7 & 0.281 \\
\hline 1991 & 77.8 & 0.908 & 73.1 & 0.932 & 35.0 & 0.218 & 39.2 & 0.282 \\
\hline 1992 & 77.6 & 0.9 & 74.0 & 0.869 & 34.3 & 0.219 & 39.0 & 0.273 \\
\hline 1993 & 78.3 & 0.866 & 74.3 & 0.928 & 33.4 & 0.220 & 39.2 & 0.297 \\
\hline 1994 & 79.1 & 0.875 & 74.9 & 0.88 & 36.0 & 0.218 & 38.5 & 0.283 \\
\hline 1995 & 79.7 & 0.907 & 75.7 & 0.974 & 33.9 & 0.231 & 40.1 & 0.298 \\
\hline 1996 & 80.1 & 0.902 & 76.0 & 1.254 & 33.9 & 0.228 & 38.4 & 0.374 \\
\hline 1997 & 80.7 & 0.887 & . & . & 31.9 & 0.225 & $\cdot$ & . \\
\hline 1998 & 80.8 & 0.887 & . & . & 29.5 & 0.223 & . & . \\
\hline 1999 & 81.6 & 0.91 & & & 33.4 & 0.219 & & \\
\hline
\end{tabular}

Source: Authors' calculations using the Current Population Survey (1981-2000) and National Health Interview Survey (1983-1996). 
Appendix Table 3. Median Household Size Adjusted Income Working Age Men and Women in the Current Population Survey (CPS), 1981-2000 by Disability Status

\begin{tabular}{|c|c|c|c|c|c|c|c|c|}
\hline \multirow[b]{3}{*}{ Year } & \multicolumn{4}{|c|}{ With Disabilities } & \multicolumn{4}{|c|}{ Without Disabilities } \\
\hline & \multicolumn{2}{|c|}{ Men } & \multicolumn{2}{|c|}{ Women } & \multicolumn{2}{|c|}{ Men } & \multicolumn{2}{|c|}{ Women } \\
\hline & Estimate & $\begin{array}{c}\text { Standard } \\
\text { Error }\end{array}$ & Estimate & $\begin{array}{c}\text { Standard } \\
\text { Error }\end{array}$ & Estimate & $\begin{array}{l}\text { Standard } \\
\text { Error }\end{array}$ & Estimate & $\begin{array}{c}\text { Standard } \\
\text { Error }\end{array}$ \\
\hline 1980 & 16,638 & 343 & 14,769 & 408 & 28,909 & 138 & 25,920 & 130 \\
\hline 1981 & 16,856 & 472 & 14,702 & 512 & 28,393 & 142 & 25,391 & 137 \\
\hline 1982 & 15,811 & 376 & 14,333 & 442 & 27,806 & 151 & 25,083 & 134 \\
\hline 1983 & 15,970 & 383 & 13,887 & 465 & 28,411 & 144 & 25,691 & 139 \\
\hline 1984 & 16,132 & 383 & 14,599 & 484 & 29,400 & 159 & 26,492 & 147 \\
\hline 1985 & 16,796 & 486 & 14,703 & 474 & 29,989 & 154 & 27,155 & 142 \\
\hline 1986 & 16,680 & 467 & 14,403 & 465 & 30,962 & 158 & 27,854 & 150 \\
\hline 1987 & 17,036 & 439 & 14,432 & 547 & 31,093 & 160 & 28,426 & 156 \\
\hline 1988 & 16,133 & 429 & 14,466 & 531 & 31,760 & 172 & 28,590 & 171 \\
\hline 1989 & 16,813 & 501 & 14,987 & 493 & 31,876 & 165 & 28,862 & 152 \\
\hline 1990 & 15,821 & 453 & 14,992 & 492 & 30,919 & 161 & 28,118 & 159 \\
\hline 1991 & 16,093 & 429 & 14,216 & 348 & 30,411 & 155 & 27,925 & 152 \\
\hline 1992 & 15,754 & 382 & 13,482 & 388 & 30,240 & 154 & 27,886 & 151 \\
\hline 1993 & 14,752 & 413 & 13,254 & 380 & 30,062 & 162 & 27,523 & 151 \\
\hline 1994 & 14,807 & 355 & 14,355 & 499 & 30,478 & 157 & 28,022 & 152 \\
\hline 1995 & 15,433 & 356 & 14,196 & 467 & 30,416 & 166 & 28,091 & 160 \\
\hline 1996 & 15,117 & 415 & 13,773 & 382 & 31,165 & 173 & 28,765 & 176 \\
\hline 1997 & 15,537 & 347 & 14,268 & 396 & 31,643 & 165 & 29,487 & 169 \\
\hline 1998 & 16,079 & 442 & 14,316 & 470 & 33,354 & 182 & 30,372 & 172 \\
\hline 1999 & 16,969 & 452 & 16,127 & 633 & 34,799 & 185 & 31,996 & 192 \\
\hline
\end{tabular}

Source: Authors' calculations using the Current Population Survey (1981-2000). 
Appendix Table 4. Tests for Differences in Time Trends Between CPS and NHIS Data, 1983-1996

\begin{tabular}{|c|c|c|c|c|}
\hline \multirow[b]{3}{*}{ Variable } & \multicolumn{4}{|c|}{ Estimated Parameter (Standard errors are in parentheses) } \\
\hline & \multicolumn{2}{|c|}{ Prevalence Rate } & \multicolumn{2}{|c|}{ Employment Rates } \\
\hline & Men & Women & Men & Women \\
\hline \multirow[t]{2}{*}{ Constant } & 7.49 & 6.91 & 39.2 & 27.4 \\
\hline & $(0.54)$ & $(0.39)$ & $(1.16)$ & $(1.01)$ \\
\hline \multirow[t]{2}{*}{ Time } & 0.79 & 0.54 & 1.34 & 1.82 \\
\hline & $(0.46)$ & $(0.33)$ & $(0.36)$ & $(0.30)$ \\
\hline \multirow[t]{2}{*}{ Time $^{2}$} & -0.27 & -0.21 & -0.12 & -0.1 \\
\hline & $(0.12)$ & $(0.09)$ & $(0.02)$ & $(0.02)$ \\
\hline \multirow[t]{2}{*}{ Time $^{3}$} & 0.03 & 0.02 & & \\
\hline & $(0.01)$ & $(0.01)$ & & \\
\hline \multirow[t]{2}{*}{ Time $^{4}$} & -0.001 & -0.001 & & \\
\hline & $(0.0004)$ & $(0.0003)$ & & \\
\hline \multirow[t]{2}{*}{ NHIS } & 3.65 & 3.49 & 10.7 & 1.91 \\
\hline & $(0.96)$ & $(0.71)$ & $(2.29)$ & $(1.72)$ \\
\hline \multirow[t]{2}{*}{ NHIS*Time } & -1.02 & 0.05 & -0.68 & 0.28 \\
\hline & $(0.83)$ & $(0.61)$ & $(0.68)$ & $(0.51)$ \\
\hline \multirow[t]{2}{*}{ NHIS*Time ${ }^{2}$} & 0.17 & -0.1 & 0.04 & -0.004 \\
\hline & $(0.21)$ & $(0.16)$ & $(0.04)$ & $(0.03)$ \\
\hline \multirow[t]{2}{*}{ NHIS*Time ${ }^{3}$} & -0.01 & 0.02 & & \\
\hline & $(0.02)$ & $(0.02)$ & & \\
\hline \multirow[t]{3}{*}{ NHIS*Time ${ }^{4}$} & 0.0002 & -0.001 & & \\
\hline & $(0.0007)$ & $(0.0005)$ & & \\
\hline & \multicolumn{4}{|c|}{ F-Test on the Interaction Coefficients } \\
\hline F-Statistic & 2.04 & 2.69 & 0.6 & 1.64 \\
\hline $\operatorname{Prob}(\mathrm{F}>\mathrm{Fc})$ & 0.13 & 0.06 & 0.56 & 0.22 \\
\hline
\end{tabular}

Note: To adjust for the fact that the dependent variables are estimates, all regressions are weighted by the reciprocal of the their standard errors.

Source: Authors' calculations using the Current Population Survey (1981-2000) and National Health Interview Survey (1983-1996). 


\section{Appendix Table 5. Tests for Differences in Trends in Employment Rates by Decade and Gender}

\begin{tabular}{|c|c|c|c|c|}
\hline \multirow[b]{3}{*}{ Variable } & \multicolumn{4}{|c|}{ Estimated Parameter (Standard errors are in parentheses.) } \\
\hline & \multicolumn{2}{|c|}{ 1980s } & \multicolumn{2}{|c|}{$1990 \mathrm{~s}$} \\
\hline & Men & Women & Men & Women \\
\hline \multirow[t]{2}{*}{ Constant } & 96.9 & 68.3 & 96.2 & 77 \\
\hline & $(3.59)$ & $(1.05)$ & $(3.22)$ & $(2.61)$ \\
\hline \multirow[t]{2}{*}{ Time } & -0.54 & 0.59 & -0.49 & 0.32 \\
\hline & $(1.51)$ & $(0.45)$ & $(1.35)$ & $(1.09)$ \\
\hline \multirow[t]{2}{*}{ Time2 } & 0.05 & 0.03 & 0.04 & 0.01 \\
\hline & $(0.13)$ & $(0.04)$ & $(0.12)$ & $(0.10)$ \\
\hline \multirow[t]{2}{*}{ Disability } & -52.8 & -40 & -52.2 & -42 \\
\hline & $(3.78)$ & $(1.19)$ & $(3.41)$ & (2.90) \\
\hline \multirow[t]{2}{*}{ Disability*Time } & -0.41 & -0.69 & -0.97 & -0.35 \\
\hline & $(1.59)$ & $(0.50)$ & $(1.43)$ & $(1.21)$ \\
\hline \multirow[t]{3}{*}{ Disability*Time ${ }^{2}$} & 0.05 & 0.07 & 0.01 & -0.05 \\
\hline & $(0.14)$ & $(0.04)$ & $(0.13)$ & $(0.11)$ \\
\hline & \multicolumn{4}{|c|}{ F-Test on the Interaction Coefficients } \\
\hline F-Statistic & 0.12 & 1.53 & 3.9 & 5.19 \\
\hline $\operatorname{Prob}(F>F c)$ & 0.88 & 0.25 & 0.05 & 0.02 \\
\hline
\end{tabular}

Note: To adjust for the fact that the dependent variables are estimates, all regressions are weighted by the reciprocal of the their standard errors.

Source: Authors' calculations using the Current Population Survey (1981-2000). 
Appendix Table 6. Employment Rates for Working-Age Men and Women Controlling for Changes in Age, Race, Education, and Household Size by Disability Status

\begin{tabular}{|c|c|c|c|c|c|c|c|c|c|c|c|c|c|}
\hline \multirow{3}{*}{ Work Year } & \multicolumn{6}{|c|}{ Employment Rate } & Change & \multicolumn{6}{|c|}{ Percentage Change } \\
\hline & \multicolumn{2}{|c|}{ Actual } & \multicolumn{2}{|c|}{ Reweight to 1980} & \multicolumn{2}{|c|}{ Reweight to 1989} & & \multicolumn{2}{|c|}{ Actual } & \multicolumn{2}{|c|}{ Reweight to 1980} & \multicolumn{2}{|c|}{ Reweight to 1989} \\
\hline & \multicolumn{13}{|c|}{ Men } \\
\hline & $\begin{array}{c}\text { With } \\
\text { Disabilities }\end{array}$ & $\begin{array}{c}\text { Without } \\
\text { Disabilities }\end{array}$ & $\begin{array}{c}\text { With } \\
\text { Disabilities }\end{array}$ & $\begin{array}{c}\text { Without } \\
\text { Disabilities }\end{array}$ & $\begin{array}{c}\text { With } \\
\text { Disabilities }\end{array}$ & $\begin{array}{c}\text { Without } \\
\text { Disabilities }\end{array}$ & & $\begin{array}{c}\text { With } \\
\text { Disabilities }\end{array}$ & $\begin{array}{c}\text { Without } \\
\text { Disabilities }\end{array}$ & $\begin{array}{c}\text { With } \\
\text { Disabilities }\end{array}$ & $\begin{array}{c}\text { Without } \\
\text { Disabilities }\end{array}$ & $\begin{array}{c}\text { With } \\
\text { Disabilities }\end{array}$ & $\begin{array}{c}\text { Without } \\
\text { Disabilities }\end{array}$ \\
\hline & & & & & & & 1980-1992 & -2.1 & -1.8 & -3.3 & -1.7 & - & - \\
\hline 1980 & 42.6 & 96.7 & 42.6 & 96.7 & - & - & 1982-1989 & 5.1 & 1.0 & 2.6 & 0.8 & - & - \\
\hline 1982 & 41.7 & 95.0 & 41.2 & 95.0 & - & - & 1980-1989 & 3.0 & -0.7 & -0.7 & -1.0 & - & - \\
\hline 1989 & 43.9 & 96.0 & 42.3 & 95.8 & 43.9 & 96.0 & 1989-1992 & -5.4 & -1.4 & -12.3 & -1.4 & -9.3 & -1.3 \\
\hline 1992 & 416 & 94.7 & 37.4 & 94.5 & 40.0 & 94.8 & 1992-1999 & -20.4 & 0.4 & -20.6 & 0.2 & -18.6 & -9.3 \\
\hline \multirow[t]{4}{*}{1999} & 33.9 & 95.1 & 30.4 & 94.7 & 33.2 & 95.2 & 1989-1999 & -25.7 & -0.9 & -32.7 & -1.2 & -27.8 & -0.8 \\
\hline & \multicolumn{13}{|c|}{ Women } \\
\hline & $\begin{array}{c}\text { With } \\
\text { Disabilities }\end{array}$ & $\begin{array}{c}\text { Without } \\
\text { Disabilities }\end{array}$ & $\begin{array}{c}\text { With } \\
\text { Disabilities }\end{array}$ & $\begin{array}{c}\text { Without } \\
\text { Disabilities }\end{array}$ & $\begin{array}{c}\text { With } \\
\text { Disabilities }\end{array}$ & $\begin{array}{c}\text { Without } \\
\text { Disabilities }\end{array}$ & & $\begin{array}{c}\text { With } \\
\text { Disabilities }\end{array}$ & $\begin{array}{c}\text { Without } \\
\text { Disabilities }\end{array}$ & $\begin{array}{c}\text { With } \\
\text { Disabilities }\end{array}$ & $\begin{array}{c}\text { Without } \\
\text { Disabilities }\end{array}$ & $\begin{array}{c}\text { With } \\
\text { Disabilities }\end{array}$ & $\begin{array}{c}\text { Without } \\
\text { Disabilities }\end{array}$ \\
\hline & & & & & & & 1980-1992 & 2.8 & 0.0 & -0.2 & -0.9 & - & - \\
\hline 1980 & 28.5 & 69.2 & 28.5 & 69.2 & - & - & 1982-1989 & 24.3 & 10.7 & 17.7 & 8.2 & - & - \\
\hline 1982 & 29.3 & 69.2 & 28.4 & 68.6 & - & - & 1980-1989 & 27.0 & 10.7 & 17.5 & 7.3 & - & - \\
\hline 1989 & 37.4 & 77.0 & 34.0 & 74.4 & 37.4 & 77.0 & 1989-1992 & -8.9 & 0.8 & -15.1 & -0.4 & -13.7 & -0.5 \\
\hline 1992 & 34.2 & 77.6 & 29.2 & 74.1 & 32.6 & 76.6 & 1992-1999 & -2.7 & 4.9 & -7.8 & 5.2 & -7.0 & 4.6 \\
\hline 1999 & 33.3 & 81.5 & 27.0 & 78.1 & 30.4 & 80.2 & 1989-1999 & -11.6 & 5.7 & -22.9 & 4.8 & -20.7 & 4.1 \\
\hline
\end{tabular}

Source: Authors' calculations based on the March Current Population Survey, 1981-2000. 